ROCZNIKI KULTUROZNAWCZE

Tom XI, numer $1 \quad-\quad 2020$

DOI: http://dx.doi.org/10.18290/rkult.2020.11.1-2

KRYSTYNA ROMANISZYN

\title{
W OBLICZU KOŃCA EUROPY, JAKĄ ZNAMY
}

\section{WPROWADZENIE}

Przybywa diagnoz dotyczących krytycznego stanu, w jakim znalazła się obecnie Europa i jej cywilizacja. Na poczesnym miejscu plasują się w nich czynniki demograficzne, związane ze spadkiem dzietności i starzeniem się społeczeństw europejskich. Jako remedium na tę przypadłość, utrzymującą się od kilku dekad i prognozowaną na dalsze dekady, aplikowana jest od pewnego czasu masowa imigracja ekonomiczna z mniej zamożnych krajów europejskich i spoza Europy. W ostatnich zaś latach toczące się wojny i konflikty zbrojne na świecie, które wzmogły presję migracyjną na Europę, zwłaszcza na jej zamożne kraje, dały też asumpt do wprowadzania w nich polityki migracyjnej, streszczonej w słowach „serdecznie witamy” i skierowanej do przybyszów nazwanych uchodźcami. Należy zauważyć, że zarówno niebywała otwartość europejskich krajów przyjmujących, przede wszystkim Niemiec, nielicząca się z opinią publiczną, jak i orientacja przybyszów na zamożne kraje, w tym właśnie Niemcy, wyraźnie wskazują na ścisły splot motywacji ekonomicznych i politycznych, i to po obydwu stronach: rządów przyjmujących i osób przyjmowanych. W przypadku tych pierwszych przyjmowanie uchodźców, czyli ludności z terenów objętych konfliktem, szło w parze - wskutek niewłaściwych procedur i zachęcania do przybycia $\mathrm{z}$ akceptacją tysięcy osób z krajów nieobjętych żadną wojną i legitymujących się fałszywymi dokumentami ${ }^{1}$. Z kolei emigranci zwani uchodźcami często są motywowani do opuszczenia swojego kraju także lub przede wszy-

Prof. dr hab. KRYSTYNA RoMANISZYN - Uniwersytet Jagielloński, Wydział Filozoficzny, Instytut Socjologii; adres do korespondencji — e-mail: krystyna.romaniszyn@uj.edu.pl. ORCID: http://orcid.org/0000-0002-5800-3007.

${ }^{1} \mathrm{~W}$ doniesieniach prasowych przewijała się liczba ponad stu krajów świata, z których przybywali imigranci w czasie tzw. kryzysu migracyjnego. 
stkim racjami ekonomicznymi. I nie jest to czymś nowym, albowiem już od ponad dwóch dekad obserwuje się na świecie tendencję splatania się politycznych motywów migracji z ekonomicznymi. Jak pisałam przed laty, dostępnym materiałem dowodowym, pozwalającym analizować wskazany splot, są raporty z badań prowadzonych pod auspicjami Międzynarodowej Organizacji ds. Migracji (IOM)². Na przykład już w 1994 r. w raporcie dotyczącym migracji tranzytowej przez Bułgarię stwierdza się, „że wszystkie objęte badaniem osoby starające się o status uchodźcy traktowały Bułgarię jako kraj pierwszego azylu, planując dalszą migrację do bogatych krajów Zachodu"3. Podobne wnioski płyną z przygotowanych w tym samym czasie raportów o migracji tranzytowej na Węgrzech i na Litwie. Oczywiste jest, że dla badanych imigrantów względy ekonomiczne były co najmniej równie ważne jak względy polityczne, nie można też wykluczyć, że te ostatnie traktowano jako pretekst do legalnej migracji na Zachód. Rządy zainteresowane naborem imigrantów mają, wykorzystywaną w przeszłości, możliwość liberalizacji reżimu migracyjnego obowiązującego uchodźców, polegającą na wprowadzeniu specjalnego programu pozwalającego na uznanie za uchodźcę osoby niespełniającej kryteriów genewskiej definicji tej kategorii imigrantów ${ }^{4}$. W latach 1980. rzeczoną procedurę, pod nazwą „The Polish Special Movement", stosowała Kanada wobec obywateli polskich. Podobne specjalne programy rząd kanadyjski otwierał wielokrotnie m.in. dla przybyszów z Iranu, Libanu, Sri Lanki czy Jugosławii ${ }^{5}$.

Przykłady z przeszłości poszerzają horyzont oglądu współczesnych i spodziewanych w przyszłości masowych napływów migracyjnych m.in. do Europy. Pokazują one elastyczność, by tak rzec, praktyk migracyjnych obydwu zainteresowanych stron: migrantów i rządów. To z kolei sprawia, że pojęcia odnoszące się do osób mobilnych i rodzajów migracji powstałe, ugruntowane i stosowane $\mathrm{w}$ nauce, prawodawstwie i debacie publicznej przestają denotować stan rzeczywisty. Powstały rozziew między językiem a rzeczywistością uniemożliwia jej rozumienie, a w konsekwencji rozumne działanie.

W niniejszym tekście, sytuującym się w nurcie refleksji dotyczącym kondycji współczesnej Europy, skupię uwagę na zagrożeniach dla społeczeństw

\footnotetext{
${ }^{2}$ Krystyna Romaniszyn, „Migracje polityczno-ekonomiczne jako fenomen współczesności”, w: Migracje polityczne XX wieku, red. Jan E. Zamojski, seria: Migracje i społeczeństwo, t. 4 (Warszawa: Wydawnictwo Neriton, 2000), 93.

${ }^{3}$ Ibid.

${ }^{4}$ ONZ-etowska definicja określająca, jakie kryteria musi spełniać osoba uznana za uchodźcę, została sformułowana w artykule pierwszym Konwencji Genewskiej z 1951 r. i w Protokole z 1967 r.

${ }^{5}$ Obszerniej na ten temat piszę w Romaniszyn, „Migracje polityczno-ekonomiczne”, 87-88.
} 
europejskich wynikających z masowej i raptownej imigracji przede wszystkim z Afryki i Bliskiego Wschodu, skąd w ostatnich latach płynęly wielkie fale migracyjne i skąd spodziewane są następne. Kolejno podnoszone wątki dotyczą: rozmiarów imigracji do Europy, czynników wypychających z krajów pochodzenia i przyciągających do krajów europejskich, społecznych mechanizmów i kulturowych determinant mobilności, politycznego kontekstu współczesnych migracji oraz ich możliwych społecznych i kulturowych konsekwencji.

\section{NASILENIE GLOBALNEJ MOBILNOŚCI I ROSNĄCA PRESJA MIGRACYJNA NA EUROPE}

Do najbardziej charakterystycznych cech współczesności należy mobilność o zasięgu globalnym. Europa nie stanowi pod tym względem wyjątku, przeciwnie - obok Stanów Zjednoczonych jest drugim pod względem atrakcyjności i liczebności napływów obszarem przyciągającym. Mobilność w skali całego globu wzmaga się nieprzerwanie od lat 1960. Ostatnimi laty tempo wzrostu jest bardzo duże. Raport ONZ wykazuje, że w 2017 r. we wszystkich krajach świata mieszkało 258 mln osób urodzonych za granicą lub będących obywatelami innego państwa ${ }^{6}$. Od 2010 r. jest to wzrost o ponad $40 \mathrm{mln}$ (w 2010 r. poza krajem swojego pochodzenia mieszkało legalnie 213,9 mln osób) ${ }^{7}$, a od 1965 r. liczba migrantów w skali globu „wzrosła o około $140 \mathrm{mln}$, czyli o $184 \% "$ ". Znaczący udział w globalnych migracjach mają współcześnie Afrykanie. W latach 2010-2017 z samej tylko północnej Afryki przeniosło się do Europy prawie milion osób ${ }^{9}$. Z innych wyliczeń wynika, że w latach 1990-2015 łącznie z Ameryki Południowej, Afryki i Azji przeniosło się na Północ, przede wszystkim do Stanów Zjednoczonych i Europy, 44 mln ludzi ${ }^{10}$.

Prognozy dotyczące migracji do Unii Europejskiej nie są jednoznaczne. Wyraźny wzrost liczby migrantów przybywających latem i jesienią 2019 r.

\footnotetext{
${ }^{6}$ Marek OKólski i Agnieszka RAdziwinowiczównA, „Współczesne migracje na świecie”, w: 25 wyktadów o migracjach, red. Magdalena Lesińska i Marek Okólski (Warszawa: Wydawnictwo Naukowe Scholar, 2018), 101.

${ }^{7}$ Marek Око́Lski i Agnieszka Finel, Demografia. Wspótczesne zjawiska i teorie (Warszawa: Wydawnictwo Naukowe Scholar, 2012), 204.

${ }^{8}$ Ibid.

${ }^{9}$ Za: Pew Research Center, dostęp 04.11.2018, http//www.pewglobal.org/2018/03/22.

${ }^{10}$ David Frum, „How much immigration is too much?” The Altantic 2019, April issue: 66. https:/www.theatlantic.com/magazine/archive/2019/04/david-frum-how-much-immigration-is-toomuch/ 583252/
} 
na greckie wyspy na Morzu Egejskim skłonił ministra niemieckiego MSW do stwierdzenia, że Europa znajduje się u progu nowej, potężnej fali migracyjnej z Południa, w tym z Afryki, znacznie silniejszej niż ta z 2015 r. ${ }^{11}$ $\mathrm{Z}$ kolei, jak informuje unijna agencja Frontex, w listopadzie 2019 r. liczba wykrytych przypadków nielegalnego przekroczenia granic UE na głównych europejskich szlakach migracyjnych spadła o 25 procent w porównaniu z poprzednim miesiącem i wynosiła ok. 14,4 tys. osób ${ }^{12}$. Należy dodać, że stwierdzany spadek może być podyktowany porą roku czy chwilową lub stałą zmianą szlaku wędrówki i nie daje podstaw do orzekania o osłabieniu presji migracyjnej na Europę. Takich podstaw nie dają też niewygasające konflikty i walki na Bliskim Wschodzie. Dodatkowo pojawiają się ekoargumenty, dotyczące orzekanych przemian klimatycznych, mających w nieodległym czasie uniemożliwić życie w Afryce Subsaharyjskiej, co wymusiłoby i uzasadniało masową migrację jej obecnych mieszkańców na Północ.

\section{OBIEKTYWNE CZYNNIKI WYPYCHAJĄCE I PRZYCIĄGAJĄCE DOTYCZACE EKSODUSU Z AFRYKI}

Powszechnie wskazuje się na dwa obiektywne czynniki wypychające z Afryki i przyciągające do światowych enklaw dobrobytu i spokoju, w tym do Europy. Są to bieda oraz konflikty zbrojne. Według egipskiego urzędu statystycznego obecnie $1 / 4$ młodych mężczyzn obywateli tego kraju wyjechałaby do pracy za granicą, gdyby mogła, a ponad połowa mieszkańców Kenii i RPA pragnie emigrować, podobnie jak $3 / 4$ obywateli Ghany i Nigerii, przy czym gotowość do migracji deklarują osoby młode, ponadprzeciętnie w porównaniu z rodakami - wykształcone i o relatywnie wysokim poziomie życia w swoim kraju ${ }^{13}$. Są to zatem osoby o najwyższym — w skali swojego kraju - kapitale ludzkim. Ich masowa emigracja gwarantuje postępującą depopulację i utrwalenie stanu zacofania gospodarczego kraju macierzystego, jednej z głównych przyczyn planowanych i faktycznych odpływów migracyjnych z regionu. Potwierdzenie znajdują, niestety, przewidywania sprzed ponad dwudziestu lat:

\footnotetext{
${ }^{11}$ Konrad Wysocki. „Europa u progu kolejnego kryzysu”, Gazeta Polska Codziennie z 9.10. 2019: 6. https://gpcodziennie.pl/121128-europa-uprogu-kolejnego-kryzysu.html.

${ }^{12}$ Notatka zatytułowana „Słabnie fala nielegalnej imigracji”, Gazeta Polska Codziennie z 17. 12.2019: 6

${ }^{13}$ Frum, „How much immigration”, 67. Wprawdzie nie znamy kierunku ich potencjalnej migracji, lecz przetarte szlaki migracyjne wskazują na Europę i USA.
} 
utrzymywanie się międzynarodowego podziału pracy i wiążący się z tym nierówny podział bogactwa oraz radykalne różnice poziomu technologicznego i ekonomicznego będą nadal czynnikiem pobudzającym masowe migracje zarobkowe i współokreślającym ich szlaki ${ }^{14}$.

Powstała i utrzymująca się spirala, z jednej strony, niskiego poziomu życia lub wręcz biedy i braku rozwoju gospodarczego, a z drugiej strony stałego odpływu najwartościowszego kapitału ludzkiego, wywołanego głównie lub także przez te czynniki, nadal daje pewność trwałości presji migracyjnej z tych krajów i regionu świata na światowe enklawy dobrobytu. Płynie z tego wniosek, że dobrobytem należy śpiesznie zacząć się dzielić, zanim dzielić się nim zaczną sami zainteresowani w sposób przez nich przyjęty, czyli przez masowe napływy osób o niemałych oczekiwaniach konsumpcyjnych i umiejętnościach często nieadekwatnych do potrzeb rynku pracy zamożnych dziś krajów europejskich. O potrzebie rozpoznania i przeciwdziałania mechanizmom ekonomicznym, finansowym i społecznym umacniającym „stan bogactwa jednych i ubóstwa drugich” pisał wiele lat temu Ojciec Święty Jan Paweł II, przestrzegając: „powinno być oczywiste, że rozwój albo stanie się powszechny we wszystkich częściach świata, albo ulegnie procesowi cofania się również $w$ strefach odznaczających się stałym postępem"15. Nie maleje, lecz wzrasta aktualność tej diagnozy i przestrogi zarazem, która jak dotąd nie stała się ani kierunkowskazem, ani miernikiem rzeczywistych działań.

Szeroki kontekst interpretacyjny wskazanych przyczyn migracji - stanowiony przez fakt nierówności rozwoju gospodarczego w skali globu, skutkującej powstaniem i utrwaleniem się światowych centrów bogactwa i dobrobytu oraz peryferii biedy i zacofania gospodarczego - należy uzupełnić przez wskazanie specyficznego sposobu penetrowania owych peryferii przez wielki kapitał napływający z centrów. Problem dotyczy wielkich korporacji czy ogólniej wielkiego kapitału kierującego się ku Afryce celem pozyskiwania jej zasobów i zaciekle rywalizującego między sobą, kosztem społeczeństw poddanych tym wpływom i działaniom. Podejmując rzeczoną kwestię, kard. Robert Sarah, z pochodzenia Afrykanin, pyta: „Kto wywołał wojny i nędzę, które skłaniają Afrykanów do ucieczki ze swoich krajów?” i

\footnotetext{
${ }^{14}$ Krystyna Romaniszyn, „Światowe szlaki migracyjne: przemiany i kontynuacje”, w: Migracje 1945-1995, red. Jan E. Zamojski, seria: Migracje i społeczeństwo, t. 3 (Warszawa: Wydawnictwo Neriton, 1999), 67.

${ }^{15}$ Por. Jan Pawet II, Encyklika Sollicitudo rei socialis, w: Encykliki Ojca Świętego Jana Pawła II Dom (Kraków: Dom Wydawniczy Rafael, 2009), 286-287.
} 
udziela odpowiedzi: „Całe narody są pustoszone ekonomiczne przez pozbawione skrupułów korporacje międzynarodowe, rabujące gospodarki krajowe. Różne formy polityki neokolonialnej, która wyklucza rządy, to hańba"16. O aktywności wielkich korporacji żerujących na afrykańskich zasobach Witold Kieżun pisał zaś następująco:

Wymordowanie ok. 800 tys. w Rwandzie i ok. 460 tys. w Kongu to niezamierzony, ale łatwy do przewidzenia efekt wielkiej akcji zespołu koncernów anglosaskich dotyczącej zdobycia bogactw mineralnych Afryki Centralnej. To straszny efekt morderczej walki o zysk. Widziałem to, czego prawie nikt w Polsce nie widział: zbrodniczość wielkiego kapitału inicjatora walki, za wszelką cenę, bez żadnych skrupułów moralnych, o nowe rynki, o zniszczenie konkurentów ${ }^{17}$.

Zastanawiające jest, że problem morderczej konkurencji wielkich firm i jej skutki, katastrofalne dla społeczeństw, których ona bezpośrednio dotyczy, nie zaprzątają uwagi zatroskanych o uchodźców z Afryki. Gdy tymczasem nie co innego, jak właśnie, mówiąc obrazowo, wielkie pieniądze żerujące w Afryce podsycają wewnętrzne konflikty, ingerują w sferę polityki i przyczyniają się do utrwalania się biedy i zacofania gospodarczego tamtejszych społeczeństw. Owa aktywność jest istotnym, ale - przypadkowo czy celowo? - niezauważanym współczynnikiem afrykańskiego „,pospolitego ruszenia”, m.in. na Europę. W miejsce gruntownych i systemowych działań nakierowanych na zmianę relacji gospodarczych między afrykańskimi peryferiami a światowymi centrami kapitału tak, by służyły one rozwojowi gospodarczemu tych pierwszych stosowane są doraźne środki pomocy humanitarnej i gospodarczej. Tę pierwszą podejmują przede wszystkim organizacje pozarządowe świeckie i kościelne. Ta druga płynie wprawdzie z UE, nie spełni jednak swojego zadania bez skrupulatnego rozliczania sposobu wydatkowania środków unijnych, czyli miliardów euro rokrocznie przeznaczanych na ten cel. Takie rozliczenie zwykle nie ma miejsca. Tymczasem w afrykańskich społeczeństwach żelazną, bo kulturową regułą działania jest wspomaganie członków swego plemienia czy klanu. W naszym rozumieniu jest to nepotyzm. Jeśli do tego dojdzie korupcja, która oczywiście ma miejsce, wówczas przesyłane środki nie mogą posłużyć gospodarczemu podźwignięciu się tych społeczeństw, a tylko utrwalają w nich ogromne rozwarstwienie

\footnotetext{
${ }^{16}$ Por. Robert SARAH i Nicolas Diat, Wieczór się zbliża i dzień już się chyli (Warszawa: Wydawnictwo SS. Loretanek, 2019), 372.

${ }^{17}$ Witold Kieżun, Patologia transformacji (Warszawa: Wydawnictwo Poltext, 2012), 109. Notabene również o wojnie w Syrii mówi się, że walka o dostęp do ropy naftowej jest jej nieostatnim powodem.
} 
majątkowe ${ }^{18}$. Bez wątpienia ,jedyne trwałe rozwiązanie wiąże się z gospodarczym rozwojem Afryki”"19. Tymczasem tym, co rzeczywiście ulega utrwalaniu, jest stan braku szans na polepszenie poziomu życia całych afrykańskich społeczeństw. I nie dzieje się to przypadkiem:

Bogaci mają powołanie do coraz większego wzbogacania się, podczas gdy ubodzy mają niezmiennie trwać w niedostatku. Humanistyczne dyskursy to kłamliwy blichtr. Elity nie życzą sobie zmiany. Sentymentalizm i tania litość zastępuje działanie ${ }^{20}$.

Obecnie trwały jest jedynie kontrast między, z jednej strony, przeciętnym poziomem życia społeczeństw afrykańskich, a z drugiej strony europejskich. Podobnie utrzymujący się stan napięć politycznych, przeradzających się w konflikty zbrojne na kontynencie afrykańskim, kontrastuje ze względnym spokojem w europejskich krajach docelowych. Ów splot czynników ekonomicznych i politycznych stanowi podłoże migracji i stale buduje presję migracyjną z tego kontynentu, przede wszystkim na Europę i Stany Zjednoczone.

Pozostaje pytanie o obiektywne czynniki przyciągające. Odpowiadają one wskazanym czynnikom wypychającym i są to łącznie oczekiwanie spokojnego i dostatniego życia dla siebie i w przyszłości także dla rodziny pozostawionej jeszcze w Afryce. Na czyj koszt oczekiwania te mogą zostać spełnione? W postprzemysłowych społeczeństwach zachodnich, w których rynek pracy cechuje elastyczność, a stanowisk pracy ubywa także w związku z postępującą i mającą nabierać przyśpieszenia robotyzacją nie ma wakatów dla setek tysięcy, o milionach nie wspominając, przybyszów, których kwalifikacje dodatkowo redukują szansę na znalezienie i zachowanie pracy czy realizację kariery zawodowej. Ta zaś stanowi nie tylko podstawą samodzielnego utrzymania, ale jest ścieżką prowadzącą do ekonomicznej adaptacji w społeczeństwie. Na przybyszów nie czeka też praca, lecz obozy przejściowe, w których tkwią bezczynnie całymi miesiącami. Koszty ich utrzymania, podobnie jak środki przeznaczane na zasiłki, spadają na społeczeństwo przyjmujące ${ }^{21}$, niepytane o opinię w tej kwestii. Nie jest to sytuacja satysfakcjonująca którąkolwiek ze stron. Po stronie społeczeństwa ponoszącego wielorakie, nie tylko finansowe, koszty napływu imigrantów pogłę-

\footnotetext{
${ }^{18}$ Jest ono widoczne gołym okiem na przykład w stolicy Kenii w kontrastujących z sobą dzielnicach skrajnej nędzy dla milionów i niebywałego luksusu dla nielicznych.

${ }^{19}$ SARAH i DiAT, Wieczór się zbliża, 327.

${ }^{20}$ Ibid., 372.

${ }^{21}$ Wedle uzyskanych informacji w zachodnich Niemczech w jednej z prywatnych placówek świadczącej usługi rehabilitacyjne właściciel zarządza darmową pracę w soboty dla uzyskania środków z przeznaczeniem na zasiłki dla imigrantów zamieszkujących w miasteczku.
} 
bia się dystans, z czasem niechęć, a także wrogość wobec nich, o czym dalej. Sami zaś przybysze mają możliwość skonfrontowania oczekiwań z rzeczywistością, na niekorzyść tych pierwszych. Na początek jest to bowiem rzeczywistość obozowa, często niedająca możliwości prowadzenia spokojnego życia $^{22}$ i odsuwająca tę perspektywę w odległą przyszłość. W tej sytuacji może łatwo dochodzić do kulturowego i religijnego wykorzenienia „Afrykanów rzuconych w kraje zachodnie, które same przechodzą bezprecedensowy kryzys”, łącznie staje się to iście „śmiertelną mieszanką". ${ }^{23}$

\section{SPOŁECZNE MECHANIZMY I KULTUROWE DETERMINANTY MOBILNOŚCI}

Wśród społecznych mechanizmów mobilności na szczególną uwagę zasługują sieci migracyjne oraz zorganizowany przemyt ludzi. Wśród determinant kulturowych istotne są wyobrażenia o dobrobycie i łatwości życia w Europie dla wszystkich chętnych oraz łatwość i dostępność komunikacji za pośrednictwem technologii internetowych.

Sieci migracyjne są podstawowym społecznym mechanizmem wspomagającym migracje także współcześnie ${ }^{24}$. Owe sieci, tworzone przez trwałe, niesformalizowane relacje oparte na zaufaniu i zasadzie wzajemności, łączą osoby mobilne z (aktualnie) niemobilnymi. Silne sieci migracyjne powstają w kręgu krewniaczym, słabsze są budowane przez relacje przyjacielskie i towarzyskie. Sieci migracyjne pełnią funkcje selekcjonujące w lokalnych społecznościach kraju wysyłającego, determinując, kto i dokąd wyjeżdża, oraz funkcje adaptacyjne w kraju emigracji, obniżając jej koszty finansowe i moralne. Stanowią one ważny i darzony zaufaniem kanał informacji o warunkach i możliwościach dostępnych dla przybyszów w kraju emigracji. Wyliczone cechy i funkcje sieci migracyjnych trwale wspomagają migrację na raz przetartym szlaku także w dobie powszechnego Internetu i międzynarodowych biur pośrednictwa pracy. Informacje napływające $z$ badań wskazują na ich niesłabnący udział w podtrzymywaniu migracji. Nie inaczej jest w przypadku współczesnych masowych napływów z Afryki do Europy.

\footnotetext{
${ }^{22} \mathrm{~W}$ obozach dla uchodźców ma miejsce przemoc, której ofiarą padają słabsi, a także chrześcijanie, dochodzi w nich też do konfliktów i walk między sunnitami i szyitami.

${ }^{23}$ SARAH i Diat, Wieczór się zbliża, 327.

${ }^{24} \mathrm{~W}$ studiach migracyjnych zarówno pojęcie „sieci migracyjnych”, jak i ich empiryczne świadectwa są wręcz na porządku dziennym.
} 
Inny ważny społeczny mechanizm służący wpierw inicjowaniu, a następnie wspomaganiu migracji na danym szlaku to werbownictwo. Wydawać by się mogło, że ta instytucja należy li tylko do przeszłości migracji. W rzeczywistości ma się ona dobrze w czasach nam współczesnych, zmianie uległy tylko jej formy i skala. Tradycyjnie werbownik, opłacany przez przewoźników od każdej zwerbowanej osoby, przemierzał wsie i miasteczka, zachęcając usilnie do migracji i przedstawiając kraj docelowy jako ziemską idyllę. O skuteczności tej pracy informują rozmiary, jakie przybierała migracja z terenów, które przemierzył werbownik. Na ziemiach polskich dwóch zaborów, rosyjskiego i austriackiego, dziełem tych osób była tak zwana „gorączka brazylijska”, która na przełomie XIX i XX wieku objęła około 100 tysięcy osób migrujących do Brazylii.

Współcześnie rolę i zajęcie zarobkowe werbownika w społeczeństwach afrykańskich przejęły niektóre organizacje pozarządowe z krajów docelowych. Nieco światła na tę mroczną sferę rzucają fakty podawane przez kard. Saraha: „Cóż to za dziwne organizacje humanitarne przemierzające Afrykę, nakłaniające młodych ludzi do ucieczki obietnicami lepszego życia w Europie? [...] Mafijne sieci przemytników ludzi trzeba wyplenić z największą stanowczością" 25 . W literaturze przedmiotu już wiele lat temu zwrócono uwagę, że czynnikiem powodującym wzrost migracji w XX wieku jest prowadzona $\mathrm{w}$ skali światowej działalność międzynarodowych organizacji humanitarnych ${ }^{26}$. Współcześnie masowe migracje aktywnie popierają także różne proimigranckie organizacje, religijne i świeckie. W Stanach Zjednoczonych uwagę zwraca organizacja o nazwie National Immigration Forum, dofinansowywana przez Fundację George'a Sorosa. Rola wszystkich tych organizacji $w$ powstawaniu fal migracji, łącznie $\mathrm{z}$ tymi klasyfikowanymi jako polityczne (przymusowe), jest współcześnie zdecydowanie niedoszacowana. Nie ulega wątpliwości, że w analizach dotyczących trzeciego sektora (organizacji pozarządowych), omawiających patologie w nim powstające, należy pilnie skoncentrować uwagę na organizacjach humanitarnych zajmujących się „pozyskiwaniem” imigrantów jako uchodźców. Te organizacje są bowiem w pewien sposób chronione przed podejrzeniem o nadużycia przez szyld „humanitarne”, którym niekiedy niestety posługują się cynicznie. O procederze ,pozyskiwania” imigrantów, w tym przyszłych azylantów, czytamy:

\footnotetext{
${ }^{25} \mathrm{~W}$ innym miejscu kard. Sarah powtarza, że „,potęgi mafijne” odgrywają ,„pierwszoplanową rolę w kierowaniu ruchami migracyjnymi" nie tylko z Libii do Europy. Por. SARAH i DiAT, Wieczór się zbliża, 373.

${ }^{26}$ Janina DACYL, An emerging international temporary protection regime, w: Likeverdighet og utestengning - forskningsmessige utfordringer, red. John Ch. Knudsen (Sztokholm: TemaNord, 1996), 179.
} 
Za każdym razem przed wypłynięciem w morze przemytnicy kontaktują się z włoskim centrum koordynacji ratownictwa morskiego $\mathrm{i} w$ ten sposób europejskie statki przejmują transporty migrantów bezpośrednio na morzu, żeby je dostarczyć do właściwego portu. [...] Tu nie ma żadnej tajemnicy, wszystko jest jawne. Wiadomo, że przemytnicy zaopatrują się w statki. Wiadomo, że Turcja wydaje fałszywe paszporty, a władze krajów docelowych wolą przymykać oczy. Wywiad francuski zna najdrobniejsze szczegóły przemytu migrantów z Afryki ${ }^{27}$.

Cytowany przez kard. Saraha generał Christophe Gomart, były dowódca francuskiej Dyrekcji Wywiadu Wojskowego, stwierdził:

Ta inwazja Europy przez migrantów jest zaprogramowana, kontrolowana i akceptowana. [...] W nielegalnym ruchu migracyjnym na Morzu Śródziemnym nie ma niczego, o czym nie wiedziałyby wojskowe i cywilne władze Francji ${ }^{28}$.

Warto zwrócić uwagę na kontrast między powyższymi suchymi i rzeczowymi stwierdzeniami dotyczącymi kulis współczesnych masowych migracji z Afryki do Europy a łzawymi lub mrożącymi krew w żyłach zdjęciami i filmikami rozpowszechnianym w mediach i Internecie, kierowanymi do opinii publicznej w krajach europejskich celem jej formowania.

Migracje były i są nadal źródłem (niemałych) dochodów dla osób, organizacji i instytucji trudniących się wspomaganiem mobilności. Migracje legalne stanowią źródło zarobku i utrzymania różnego rodzaju firm odpowiadających na potrzeby migrantów, poczynając od firm przewozowych. $\mathrm{Z}$ kolei migracje nielegalne, związane z przemytem ludzi, są „obsługiwane” przez międzynarodowe sieci przemytnicze, czerpiące $z$ tego procederu ogromne zyski. Zarówno skala prowadzonej działalności, jak też jej organizacja i wielkość generowanych zysków pozwala mówić wręcz o przemyśle szmuglerskim ${ }^{29}$, który rozwija się od ponad dwóch dekad, w części obejmując także terytorium Polski ${ }^{30}$. Klienci, stanowiący, ściśle mówiąc, „towar” w

\footnotetext{
27 „Agenci wywiadu wiedzieli, w których miejscach przemytnicy wymieniają się ludzkim towarem i gdzie jest on kwaterowany". Por. SARAH i DiAT, Wieczór się zbliża, 325-326

${ }^{28}$ Tamże, s. 325.

${ }^{29} \mathrm{~W}$ jednym z tekstów na ten temat czytamy: „Migrant trafficking is becoming a highly profitable and, at the same time, a well-organised illegal activity, in which use is made of modern technologies (including heavy military equipment) and of international connections between criminal groups, as well as of links between offenders and the border guards or the police". Por. Marek Око́Lsкi, „Migration Pressures on Europe”, w: European Populations: Unity in Diversity, red. Dirk van de Kaa et al. (Dordrecht: Kluwer Academic Press, 1999), 167.

${ }^{30} \mathrm{Na}$ temat nielegalnej migracji przybywającej do Polski, przy czym przeciętny czas trwania podróży do Polski to 5 miesięcy, w celu pozostania tu lub przedostania się dalej na zachód czytamy m.in.: „Smugglers offer a variety of modes of transport, including plane, train, coach, truck
} 
tym przemyśle, inwestują w przeprawę duże pieniądze własne lub pożyczone, wiedzą, dokąd i w jakim celu zmierzają, przynajmniej niektórzy z nich są też wykształceni ${ }^{31}$. W szmuglowanie ludzi stale inwestuje się też środki w formie najnowocześniejszego sprzętu. Jakiś czas temu, w grudniu 2019 r., do wybrzeży Portugalii przybiła łódź z grupą mężczyzn, nielegalnych imigrantów z Maroka, wyposażona w system nawigacji satelitarnej i z dwoma silnikami zaburtowymi ${ }^{32}$.

Kulturowe determinanty współczesnych migracji to przede wszystkim rozpowszechniane obrazy i budowane za ich pomocą wyobrażenia o życiu w światowych enklawach dobrobytu. Jak wszelkie obrazy, są konstrukcją uczynioną z wybranych elementów, nie oddają więc realiów życia w tych krajach w ogóle, w szczególe zaś tych, z którymi zmierzą się imigranci. Można zatem zasadnie mówić o tworzeniu i rozpowszechnianiu mitów o dostępności przedstawianego w nich poziomu życia dla przybyszów z Południa i o warunkach życia, jakie czekają na nich po przybyciu do Europy. Powstałe na kanwie tych mitów wyobrażenia motywują do migracji w taki sam sposób, jak opowieści XIX- i XX-wiecznych werbowników o „brazylijskim raju" motywowały owładniętych „gorączką brazylijską" mieszkańców polskich wsi. Odmienna pozostaje tylko skala oddziaływania owych kreacji. Ongiś odmierzana krokami werbownika, obecnie nieograniczona dzięki nowym technologiom komunikacji. Rewolucja w obrębie tych technologii, połączona $\mathrm{z}$ ich dostępnością, także finansową, odpowiada za łatwość, dostępność i powszechność komunikacji osób, które już podjęły migrację, i tych, które się do niej przygotowują. W czasie tzw. kryzysu migracyjnego w $2015 \mathrm{r}$. częsty był obraz tzw. uchodźców z telefonami komórkowymi. Bez wątpienia możliwość pozostawania w ciągłej łączności, dzięki owym telefonom, osób aktualnie mobilnych i już niemobilnych, bo osiadłych w kraju docelowym, a także pozostawionych w kraju pochodzenia stanowi okoliczność ułatwiającą decyzję o migracji, obniża bowiem jej moralne koszty. W ten też sposób nowe technologie komunikacyjne stanowią dopełnienie sieci migracyjnych

and passanger car. [...] Illegal migration to or through Poland [...] commands a high price, set by the smuggling organizations. [...] Around half the migrants in the sample said they had paid (or agreed to pay) US $\$ 5,000$ or more, and a quarter US $\$ 12,000$ or more”. Marek OKóLSKI, „Illegality of International Population Movements in Poland”, International Migration 38 (2000), no. 3: $72-73$.

${ }^{31}$ O pasażerach takich łodzi jeden z dziennikarzy kanadyjskich powiedział: „Every boat person I've met has been ambitious, urban, educated" [,każdy spotkany przeze mnie człowiek z łodzi był ambitny, wykształcony i pochodził z miasta”. Frum, „How much immigration”, 67.

${ }^{32}$ Notatka zatytułowana „Migracyjny strach spadł na Lizbonę”. Gazeta Polska Codziennie z 14.12.2019: 6, https://gpcodziennie.pl/124020-migracyjnystrachspadlnalizbone.html. 
w ich wskazanych uprzednio funkcjach. Jednocześnie poprzez dostępne za ich pośrednictwem wykreowane obrazy „świata Zachodu” rzeczone technologie mają swój nader realny udział w decyzji o migracji.

\section{DOBRY - POLITYCZNY - KLIMAT \\ DLA MASOWYCH MIGRACJI}

Nie ulega wątpliwości, że mamy obecnie niezwykle sprzyjający polityczny klimat dla masowych migracji z niezamożnego Południa do Europy. Przekonuje o nim szereg okoliczności. Po pierwsze, uderzająca jest radykalna zmiana retoryki dotyczącej migracji, jaka zaszła w Europie w ostatnich dekadach. Wprost niewyobrażalny jest kontrast między sposobem mówienia i nazywania masowej migracji — zarówno w przestrzeni publicznej (poprzez media), jak i w akademickiej - właściwym dla lat 1990. i obecnym. I tak w 1991 r. Time (z 26 sierpnia) pisze o nowej inwazji na Europę i tytułem "The New Invasion" ilustruje mapę Europy ze wskazanymi szlakami imigracji do Niemiec, Wielkiej Brytanii, Francji, Hiszpanii, Włoch i Grecji, ciągnącymi z Europy Środkowo-Wschodniej, w tym z Polski, oraz z Afryki i z Azji. Środowisko akademickie zaś w tamtym czasie mówi o spodziewanej masowej migracji ze Wschodu nieco oględniej, czyli przy użyciu określeń: „twierdza Europa”, „oblężenie” czy „kordon sanitarny” wokół Europy Zachodniej, budowany przez kraje środkowoeuropejskie, w tym Polskę. Kilka lat później w debacie akademickiej nie mówi się już o „oblężeniu”, lecz o potrzebie „europeizacji” w kontekście poszerzenia Unii Europejskiej na wschód. Ostatnimi laty kolejne masowe fale imigracji do Europy, w tym ich spiętrzenie w 2015 r., nie jest już w języku polityków, mediów i uczonych „inwazją”. Wręcz przeciwnie, polityce streszczającej się w słowach „serdecznie witamy" towarzyszą zupełnie nowe określenia masowych napływów jako „wzbogacających”, ${ }^{33}$, podnosi się też „wartości różnicy”, jakby różnice były wartością samą w sobie, a ostatnio mówi się o nowym humanizmie. Jak zawsze, tak i w tym przypadku zmiana retoryki nie pozostaje bez związku z rzeczywistością, do której się odnosi i którą współkształtuje. Ta zmiana pokazuje, że masowe migracje zostały uznane za ważny element obecnego i tworzonego ładu światowego.

\footnotetext{
${ }^{33}$ Jedną z bardziej spektakularnych form wzbogacania krajobrazu europejskich krajów przyjmujących jest rosnąca w nich liczba meczetów.
} 
Po drugie, o sprzyjającym politycznym klimacie dla masowych migracji nie tylko z Południa do Europy, ale w skali globalnej przekonuje przygotowanie pod auspicjami ONZ Paktu dla Migracji (The Global Compact for Safe Orderly and Regular Migration) i przyjęcie tego dokumentu przez 164 państwa 10 grudnia 2018 r. w Marrakeszu (Maroko).

Pakt powstawał dla umiędzynarodowienia, jak to określono, zarządzania światowymi procesami migracyjnymi. Zarządzanie to nie wyklucza, a wręcz przeciwnie — zakłada oraz, co nie mniej ważne, implikuje wielorakie zmiany, i to w każdej skali. Pierwszą, bodaj, poważną zmianą spowodowaną (implikowaną) przez wprowadzenie w życie Paktu będzie legalizowanie pobytu nielegalnych obecnie imigrantów w krajach-sygnatariuszach Paktu. Otworzy ono drogę do dalszej migracji i osiedlania się kolejnym chętnym, także w ramach łączenia rodzin ${ }^{34}$.

Wprowadzenie w życie założeń i ustaleń Paktu ma przynieść wymierne, wymieniane w dokumencie, korzyści. Oprócz tych zakładanych i wskazanych nieeksponowaną korzyścią masowej emigracji dla krajów wysyłających będzie rozładowanie doraźnych napięć wewnętrznych społeczno-ekonomiczno-politycznych. Ponadto upust zwykle najbardziej przedsiębiorczych obywateli będzie służył zachowaniu status quo w sferze gospodarczej i politycznej (czyli władzy) $^{35}$. Z kolei oczekiwane przelewy finansowe od emigrantów do rodzin pozostawionych w kraju pochodzenia bodaj w części wyręczą rządy w ich obowiązku dbania o warunki życia i potrzeby obywateli. Także po stronie krajów przyjmujących, de facto popierających masową imigrację, rysują się nieujęte w Pakcie korzyści natury politycznej, co dotyczy partii politycznych, dla których poparcie imigracji stanowi element walki o zdobycie lub utrzymanie władzy, oraz ekonomiczno-demograficznej, co dotyczy pozyskiwania siły roboczej, płatników podatków i konsumentów.

Po trzecie, świadectwem dobrego politycznego klimatu dla migracji jest włączenie artystów i sztuki oraz usłużnej akademii w propagowanie imigracji przez budowanie dla niej szerokiego społecznego poparcia, wzmacnianego przez (zwykle niekwestionowane) racje naukowe. Ostatnio wyrazem wprzęgnięcia sztuki $\mathrm{w}$ formowanie postaw przychylnych polityce globalnej mobilności było odsłonięcie nowego pomnika na Placu św. Piotra w Rzymie oraz wystawienie we Włoszech opery Mozarta wyreżyserowanej w sposób niosący przesłanie „wszyscy jesteśmy migrantami”. Znaczenie sztuki w formowaniu

\footnotetext{
${ }^{34}$ Krystyna Romaniszyn, „Migracje a zmiana celowa”, Studia Polonijne 40 (2019): 5-32.

${ }^{35}$ Można o tym wnioskować m.in. przez analogię z sytuacją w drugiej połowie lat 1980. w PRL, gdy władze przyzwoliły na utrudnianą dotąd masową emigrację.
} 
pożądanych wyobrażeń i postaw trudno przecenić, buduje ona bowiem „horyzont wyobrażeniowy"36, niesie też określone przesłanie i propaguje je. Do wszystkich dziedzin sztuki, a nie tylko literatury czy szerzej słowa pisanego i przekazywanego przez prasę, odnoszą się słowa i zalecenia Włodzimierza Lenina: „Pismo - to nie tylko kolektywny propagandysta i kolektywy agitator, lecz również i kolektywny organizator" ${ }^{37}$, umiejętnie wcielane w życie w ZSRS. Jest bowiem tak, jak przed laty pisał Mieczysław Gogacz:

Twórcy kultury, a więc ci, którzy wyznaczają kierunek i sposób ludzkiego myślenia i wytwarzania, są autorami nie tylko dzieła, lecz także poprzez to dzieło duchowego życia ludzi, przez co wpływają na sposób rozumienia, przeżywania i wyrażania głównie osobowych powiązań międzyludzkich ${ }^{38}$.

Jednocześnie, jak zauważa Autor, współczesną kulturę cechuje „zagubienie różnicy między rozpoznawaniem i wartościowaniem”, oznaczające, że „nie stwierdzamy, czym coś jest, lecz nasze rozpoznanie bytów utożsamiamy z wartościowaniem", którego racją jest m.in. postawa dydaktyczna ${ }^{39}$. W rzeczy samej sztuka powstająca na rzecz wsparcia polityki migracyjnej wyznacza kierunek i sposób myślenia poprzez wartościowanie, stając się celowym zabiegiem dydaktycznym na masową skalę. Także akademia włącza się do debaty społecznej (medialnej) z swoimi argumentami o zacięciu dydaktycznym, tropiąc lub wykazując w społeczeństwach przyjmujących dyskryminację imigrantów i nietolerancję wobec nich, niekiedy przybierającą postać rasizmu lub ksenofobii ${ }^{40}$. Naukowa obiektywność i rzetelność wymaga-

\footnotetext{
${ }^{36}$ Określenie za: Miriam Bratu HANSEN, „Masowe wytwarzanie doświadczenia zmysłowego. Klasyczne kino hollywoodzkie jako modernizm wernakularny”, przeł. Łukasz Biskupski, Monika Murawska, Michał Pabiś, Justyna Stępień, Tomasz Sukiennik i Monika Żurawska, w: Rekonfiguracje modernizmu, red. Tomasz Majewski (Warszawa: Wydawnictwa Akademickie i Profesjonalne, 2009), 235-266.

${ }^{37}$ Ewa DzIĘGIEL, „Warunki funkcjonowania pracy polskojęzycznej na Ukrainie sowieckiej w latach 20. i 30. XX wieku”, w: Ewa DzięGiel, Katarzyna Czarnecka, Dorota A. Kowalska i Lyudmyla Yanushevska, Polskojęzyczna prasa na Ukrainie sowieckiej w latach 1918-1939: przegląd tytutów i treści (Kraków: Instytut Języka Polskiego PAN, 2016), 59.

${ }^{38}$ Mieczysław Gogacz, Szkice o kulturze (Warszawa-Struga: Wydawnictwo Michalineum, 1985), 17.

${ }^{39}$ Ibid., 15 i 17.

${ }^{40}$ Faktem jest aktywizacja grup i ruchów neofaszystowskich, na przykład w krajach skandynawskich, jako reakcji na masowy napływ imigrantów, przede wszystkim islamskich, wszelako okolicznością, którą należy brać pod uwagę w analizie tych ruchów, jest brak społecznej konsultacji poprzedzającej ów napływ, uwzględniającej opinie społeczeństwa przyjmującego. Por. na ten temat: Krystyna RomAniszyn, „Odrodzenie rasizmu jako element przemian kulturowych implikowanych przez międzynarodowe migracje”, Studia Polonijne 23 (2002): 7-31.
} 
łaby, po pierwsze, przedstawienia kontekstu notowanych postaw i obserwowanych zachowań, po drugie zaś przynajmniej postawienia pytań dotyczących zachowań przybyszów w tych społeczeństwach, co zwykle nie ma miejsca. Bywa natomiast miejsce na głoszenie ex cathedra postulatów odpowiedniego edukowania społeczeństwa przyjmującego $0^{41}$, bez postawienia fundamentalnego pytania o przyczyny braku społecznych konsultacji poprzedzajacych realizację polityki otwartych drzwi. W rzeczy samej interesujące jest, dlaczego kwestia dotycząca życia całych społeczeństw jest wyłączona spod mechanizmów demokracji w formalnie demokratycznych krajach? „Czy zglobalizowane elity boją się odpowiedzi, jakiej może udzielić demokracja na temat ruchów migracyjnych?" 42 Formułowanymi ostatnio w akademii argumentami na rzecz konieczności masowej migracji z Afryki do Europy są te dotyczące zmian klimatycznych.

Last but not least, dobry polityczny klimat dla globalnej migracji może wynikać z długofalowych celów Superiores Incogniti, czyli jej nieznanych zwierzchników, na co uwagę zwraca następująca wypowiedź kard. Saraha, dotycząca jednej tylko kwestii:

Marzeniem zglobalizowanej elity zachodniej jest właśnie ustanowienie nowej, globalnej religii. [...] religii bez Boga, bez doktryny i bez nauczania moralnego, religii opartej na konsensusie. W rzeczywistości ta religia ostatecznie służyłaby jedynie interesom finansowym ${ }^{43}$.

Zmieszanie przedstawicieli różnych religii i cywilizacji na jednym terytorium i w ramach jednego społeczeństwa przyjmującego wybitnie przysłuży się temu celowi. I niekoniecznie jest to jedyny cel intensywnej promocji globalnej migracji.

\section{SPOŁECZNO-KULTUROWE KONSEKWENCJE MASOWEJ IMIGRACJI}

Trzema czynnikami, mającymi decydujący wpływ na zmiany społeczno-kulturowe pochodne masowej migracji, są:

\footnotetext{
${ }^{41}$ Notabene lektura niektórych apeli powstałych w akademii nasuwa skojarzenia z nieustannymi zabiegami wychowawczymi komunizmu, niezmordowanie trudzącego się wychowywaniem socjalistycznego człowieka/komunisty.

${ }^{42}$ SARAh i Diat, Wieczór się zbliża, 327.

${ }^{43}$ Ibid., 348.
} 
1) liczba przybyszów skorelowana ze stopniem ich

2) odmienności kulturowej (cywilizacyjnej) oraz

3) czasem napływu.

Masowy napływ w krótkim czasie — kilku miesięcy, roku lub kilku lat — imigrantów będących nosicielami odmiennych i odlegtych kultur lub cywilizacji nieuchronnie burzy istniejący ład w wielu obszarach życia społecznego i dlatego zasługuje na miano pokojowej inwazji. Pierwszym symptomem zburzenia ładu jest spadek bezpieczeństwa i wzrost przestępczości, co łącznie oznacza radykalne i trwałe obniżenie jakości życia dla wszystkich. Na przykład statystyki kryminalne w Niemczech, tylko te udostępniane mediom, ukazują znaczący udział imigrantów w przestępstwach dokonywanych w tym kraju: stanowiący $11,5 \%$ mieszkańców Niemiec imigranci popełniają $34,5 \%$ przestępstw, w tym $43 \%$ wszystkich zabójstw oraz $71 \%$ kradzieży kieszonkowych ${ }^{44}$. Niemiecki magazyn Deutsche Welle odnotowuje, że w szwedzkim mieście Malmö, liczącym ok. 300 tys. mieszkańców, z czego $1 \frac{1}{3}$ stanowią osoby urodzone poza Szwecją, w 2019 r. miało miejsce 29 zamachów bombowych, nie licząc kilkudziesięciu strzelanin. Badania Eurostatu wykazały, że Polska jest w Europie jednym z najbezpieczniejszych krajów dla kobiet — w świetle tych badań Polki są 49 razy bezpieczniejsze niż Brytyjki i 37 razy bezpieczniejsze niż Szwedki. W listopadzie 2019 r. w komunikacie prasowym francuskiej policji podano, że rozpoczęła ona likwidację nielegalnego obozowiska imigrantów w Paryżu w dzielnicy Porte d'Aubervilliers, zamieszkałego przez ok. 300 osób, w listopadzie tego samego roku został zlikwidowany inny obóz, liczący ok. 1600 osób, największy zaś jak dotąd, zlikwidowany w 2016 r., obóz imigrantów, liczący ok. 7 tys. osób, powstał w Calais. W Niemczech natomiast, jak komentował już trzy lata temu Hans Buschowsky:

na przełomie marca i kwietnia 2016 r. na czołówki gazet wróciły doniesienia o poczynaniach arabskich klanów. [...] Już w styczniu 2016 r. eksperci bili na alarm, że arabskie klany mają oko na nowo przybyłych muzułmanów i będą spośród nich werbować nowych członków. [...] Kryzys migracyjny dodatkowo uskrzydlił wyobraźnię i zmysł biznesowy arabskich klanów. Interes z uchodźcami stał się w międzyczasie bardziej opłacalny niż handel narkotykami ${ }^{45}$.

\footnotetext{
${ }^{44}$ Kurier Wnet, nr 63, wrzesień 2019, rubryka Telegraf, s. 2, dane za: Der Tagesspiegel, https://wnet.fm/issues/nr-63-wrzesien-2019

${ }^{45}$ Cyt. za: Olga Doleśniak-HarCZuK, „Niechciane dziecko Willkommenskultur”, Nowe Państwo 2019, $\mathrm{nr}$ 2: 76-77, dostęp: 31.07.2020, https://www.panstwo.net/4785-niechciane-dzieckowillkommens kultur.
} 
Duża fala migracji z danego obszaru wraz z następującymi po niej kolejnymi napływami buduje imigranckie (etniczne) enklawy, a następnie sprawia, że w społeczeństwie przyjmującym powstają liczebne i jednorodne etnicznie społeczności imigrantów nazwane „społeczeństwami równoległymi”. Istnienie takich, stanowionych przez imigrantów, społeczeństw, których członkowie odznaczają się silną tożsamością narodową (etniczną), niepodatną na ponowoczesne „upłynnianie”, oraz odrzucają zastany porządek prawny, zastępując go własnym, jest stwierdzane w Berlinie, Kolonii, Essen, gdzie powstały „Mała Anatolia”, „Mały Damaszek” i „Mały Bejrut”46. Notabene w tym kontekście stałe naciski na relokację imigrantów, ponawiane przez niektórych polityków UE, są nie tylko próbą wywierania jawnego przymusu na przeciwne jej państwa i społeczeństwa, lecz także próbą przymusu niejawnego wobec samych przybyszów, którym odmawia się de facto możliwości powiększania własnych skupisk etnicznych oraz społeczeństw równoległych. Fakt ten zdaje się umykać zatroskanym o los imigrantów, portretowanych jako ofiary tak zwanej grupy dominującej społeczeństwa przyjmującego.

Trudno orzekać, jaki będzie rezultat obecnej pokojowej imigracyjnej inwazji na społeczeństwa europejskie. Można wszakże podjąć namysł nad prawdopodobieństwem homogenizacji mieszanych wskutek migracji kultur i ich nosicieli bądź pokojowej koegzystencji wszystkich w ramach jednego społeczeństwa. Ale właśnie - jakiego? Czy społeczeństwa zorganizowanego w państwo narodowe czy „społeczeństwa globalnego”? Pokojowej koegzystencji służą powtarzane od lat w przestrzeni publicznej społeczeństw europejskich zaklęcia o „wartości różnorodności”, „poszukiwaniu różnorodności”, „ubogacaniu przez różnorodność”, które notabene pozostają w sprzeczności z ewentualnym procesem homogenizacji. Na rzecz pokojowej koegzystencji mogą też działać stałe zachęty do „dialogu z przybyszami” i „tolerancji wobec inności". Wszelako masowe napływy mające miejsce w krótkim czasie służą zderzeniu, a nie dialogowi. Ze swej strony zachęta do „tolerancji”, przeradzając się stopniowo w jej przymus, wytrzebia z przestrzeni publicznej krytyczne opinie o imigracji jako nietolerancyjne, uniemożliwiając tym samym jakikolwiek dialog. Ponadto, ponieważ tolerancja oznacza bezgranicznie cierpliwe znoszenie przybyszów, pytaniem jest, komu ów dialog miałby być potrzebny i jak może on być prowadzony skoro do dialogu potrzeba stron obdarzonych swobodą posiadania, wyrażania i wymiany

\footnotetext{
${ }^{46}$ „W Turcji są całe wioski żyjące z pieniędzy przesyłanych przez arabskie klany, które stamtąd przybyły w latach 80 . Willa na willi i zadowoleni z niemieckich krewnych staruszkowie". Ibid, 74-76.
} 
opinii? Wskazany sposób pojmowania i praktykowania tolerancji służy wyłącznie budowaniu kulturowej hegemonii przybyszów, ponieważ obowiązuje tylko jedną stronę kontaktu - są nią gospodarze. Między nimi a przybyszami powstaje niesymetryczna relacja, która w przypadku przybyszów $z$ byłych europejskich kolonii może być dodatkowo utrwalana przez przyjmowanie postawy ofiary Białych. Formowanie takich postaw wspomaga ekspiacyjna twórczość, także naukowa, ostatnich dekad ${ }^{47}$.

Dostrzegalna współcześnie intensywna promocja globalizmu kulturowego, anonsowanego za pomocą apeli o ,uniwersalizm”, „nowy humanizm” względnie „nowy planetarny humanizm”, ,powszechną solidarność” („,braterstwo") czy „globalny pakt edukacyjny”, wskazuje, że idea koegzystencji odmiennych kultur w ramach społeczeństw i całego globu zwolna ustępuje miejsca idei ich globalnej homogenizacji. Myślący „globalnie” widzą też potrzebę zmiany świata ${ }^{48}$, czego istotnym czynnikiem jest masowa globalna migracja. Zwraca uwagę zbieżność promocji idei globalizmu z Paktem dla Migracji (Marrakesz, 2018). Notabene, jeśli migracja została uznana za istotny czynnik globalizacji, stając się elementem idei i praktyki globalizmu - a wiele na to wskazuje - oznacza to, że masowa migracja do światowych enklaw dobrobytu będzie nadal na różne sposoby wspierana i promowana.

Pozostaje pytanie o możliwość homogenizacji kultur w ramach jednego społeczeństwa zorganizowanego w państwo narodowe. Doświadczenia krajów europejskich, które wskutek masowej imigracji stały się systemami wieloetnicznymi i wielokulturowymi, pokazują, że taka homogenizacja nie ma miejsca, nie zacierają się też granice etniczne. Przeciwnie, ulegają one wzmocnieniu, co potwierdza diagnozę sformułowaną przez Fredrika Bartha, wskazującego na brak poczucia bezpieczeństwa jako czynnika ograniczającego kontakty między grupami etnicznymi także w sytuacji potencjalnej komplementarności interesów ${ }^{49}$. W takich społeczeństwach tożsamości etniczne okazują się często nadrzędne, natomiast

\footnotetext{
${ }^{47}$ Pojętnym uczniem takiej twórczości mogło być ugandyjskie dziecko, które zwróciło się do jednego z ojców franciszkanów pracujących w tym kraju słowami: „Oddaj mi moje pieniądze”.

${ }^{48}$ Por. na przykład tzw. Deklarację Sopocką Europejskiego Forum Nowych Idei (z 27 września 2019 r.), w której stwierdza się m.in., że biznes musi przedefiniować model gospodarki kapitalistycznej i włączyć się w globalną transformację świata, czy Instruktaż kościelnego postępowania z prawicowymi tendencjami populistycznymi, opublikowany 25 czerwca 2019 r. przez Sekretariat Konferencji Episkopatu Niemiec, w którym jest mowa o „pięknym nowym świecie globalizmu”.

${ }^{49}$ Frederik BARTH, „Grupy i granice etniczne: społeczna organizacja różnic kulturowych”, w: Badanie kultury. Elementy teorii antropologicznej. Kontynuacje, red. Marian Kempny i Ewa Nowicka (Warszawa: Wydawnictwo Naukowe PWN, 2004), 375. Potwierdzeniem trafności diagnozy jest chociażby brak współdziałania na początku roku szkolnego 2019 w jednym z angielskich
} 
ograniczenia zachowania jednostki, które wynikają z jej etnicznej tożsamości, można [...] postrzegać jako absolutne [...]. Składające się na tę tożsamość konwencje moralne i społeczne stają się zaś z biegiem czasu odporne na zmianę dzięki zespoleniu ich w zestereotypizowane zbiory stanowiące cechy jednostkowej tożsamości ${ }^{50}$.

Tak uformowane tożsamości cementują grupy etniczne, utrwalając odrębność każdej z nich. Nieostatnim powodem utrwalania odrębności i ograniczania kontaktów jest gruntowna odmienność światopoglądu związana z obecnością w kulturze - krajów pochodzenia i kraju osiedlenia — sfery sacrum. „W Afryce i Azji nic nie należy do sfery profanum. Wszystko stanowi sac-

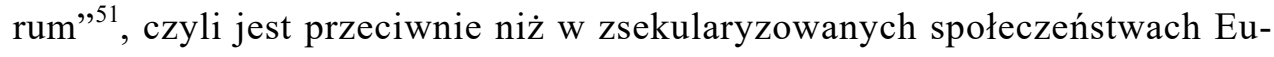
ropy. I jest to kardynalna, a nie jedynie marginalna różnica kultur. Jak więc możliwa jest i na czym miałaby polegać ich homogenizacja? Tym bardziej że „im większe są różnice pomiędzy uznawanymi wartościami, tym większe wywołują opory $\mathrm{w}$ interakcjach między grupami etnicznymi”,52. W rzeczy samej nie maleją, lecz ulegają utrwaleniu dystynkcje etniczne w europejskich społeczeństwach, które stały się wieloetniczne i wielokulturowe wskutek masowych napływów z odległych kultur. Jest to okoliczność niesprzyjająca dalszemu trwaniu państw narodowych, co skądinąd jest spójne $z$ twierdzeniami pojawiającymi się zarówno w przestrzeni publicznej, jak i w usłużnej akademii o ich rzekomym przeżytku ${ }^{53}$. Pozostaje zatem homogenizacja kultur w skali globalnej w ramach tworu, który przez analogię do określenia „globalna ekonomia” można nazwać „społeczeństwem globalnym”. Czymkolwiek by ono nie miało być, jedno nie pozostawia wątpliwości — to mianowicie, że musiałoby ono być globalnie zarządzane i nie ma w nim miejsca na narody. Upłynnianie tych ostatnich wydatnie wspomaga globalna migracja, służąc tym samym powstawaniu społeczeństwa globalnego, zarządzanie zaś procesami migracyjnymi, wpisane w Pakt o Migracji, pomoże doskonalić metody zarządzania nim. Z tej perspektywy masowa globalna migracja jawi się jako dobrze przemyślany krok ku anihilacji państw naro-

\footnotetext{
miast rodziców chrześcijańskich z muzułmańskimi, którzy nie godząc się na uczestnictwo swoich dzieci w zajęciach z edukacji seksualnej, zagrozili zabraniem ich ze szkoły.

${ }^{50}$ Ibid., s356.

${ }^{51}$ SARAH i Diat, Wieczór się zbliża, 297.

${ }^{52}$ BARTH, „Grupy i granice etniczne”, 357.

${ }^{53}$ Kilka lat temu prominentni politycy, francuski i szwedzki, obwieścili publicznie nieistnienie odpowiednio kultury francuskiej i szwedzkiej, bez której — jak wiadomo — państwo narodowe nie ma racji bytu. Wypowiedzi te potwierdziły tezę Francisa Fukuyamy, zgodnie z którą postnowoczesne elity europejskie nie identyfikują się już w kategoriach wiary i narodu.
} 
dowych, poczynając od państw europejskich ${ }^{54}$. Rzeczywiście, śledzenie wydarzeń związanych z masową migracją urealnia pojawiające się zapowiedzi budowy nowej cywilizacji, w mocy pozostawiając przestrogę przed nowymi barbarzyńskimi cywilizacjami (kard. Sarah). Bez wątpienia Europa, a także reszta świata, stoi w obliczu zmian, wszelako wpływ na nie ma także nasza wiedza i wola oraz pochodzące $\mathrm{z}$ nich nasze działanie.

\section{ZAMIAST ZAKOŃCZENIA}

W debacie dotyczącej akceptacji kolejnych fal masowej imigracji do Europy ponawiany jest apel o solidarność. W Polsce towarzyszy mu przypominanie o pomocy udzielanej swego czasu polskim uchodźcom. Warto więc odświeżać pamięć o niej. Emigracja solidarnościowa drugiej połowy lat 1980., początkowo o charakterze politycznym, a następnie polityczno-ekonomicznym, kierowała się przede wszystkim poza Europę i pobyt w obozach dla uchodźców zlokalizowanych na jej terenie miał charakter czasowy. W Grecji, gdzie nie było takich obozów, osoby podające się za prześladowanych politycznie uchodźców kwaterowano w wytypowanych i specjalnie na ten cel zarezerwowanych hotelach ateńskich.

Kieszonkowe wynoszące 200 drachm dziennie na osobę mieściło się w zakresie pomocy świadczonej do $1987 \mathrm{r}$. przez rząd grecki, sponsorowany w tej akcji przez ONZ [...] Od Polaków oczekiwano, iż swój pobyt wykorzystają na wybranie sponsora i załatwienie formalności związanych z dalszą emigracją. [...] Zwykle po kilkunastomiesięcznym pobycie w Grecji i dopełnieniu wszystkich niezbędnych formalności związanych z dalszą emigracją, które w tamtym okresie trwały wyjątkowo krótko, kolejne osoby z pierwszej solidarnościowej fali emigracji opuszczały słoneczną Helladę, kierując się najczęściej do Kanady, rzadziej do RPA, USA i Australii ${ }^{55}$.

Dodać należy, że dalsza emigracja nie wiązała się już z pobieraniem świadczeń i łączyła się z koniecznością rozpoczęcia samodzielnego życia w kraju docelowym. Warto też przypomnieć charakter pomocy udzielonej polskim

\footnotetext{
54 „Hence it may be that the admission - on a large scale - of the cultural others into the EU is just a very well calculated step to the end of European nation states and to the creation of a new socio-political reality within the realm of the EU”. Krystyna Romaniszyn, „The immigrant as a noninvented other", Studia Polonijne 39 (2018): 24.

${ }^{55}$ Krystyna Romaniszyn, „Polacy w Grecji. Cz. I: Współczesna masowa migracja zarobkowa z Polski do Grecji”. Studia Polonijne 16 (1994): 11.
} 
obywatelom, zdemobilizowanym żołnierzom oraz tzw. dipsom ${ }^{56}$ przez aliantów po zakończeniu II wojny światowej. Olbrzymia większość tych spośród nich, którzy przybywali do Australii, co miało miejsce w latach 1947-1951 i odbywało się pod auspicjami International Refugee Organization, „musiała, przybywając do Australii, zgodzić się na dwuletnią pracę w charakterze pracowników fizycznych. Ich wcześniejsze przygotowanie zawodowe i kwalifikacje oraz wykształcenie nie były zazwyczaj uwzględnianie" ${ }^{97}$. Nie inaczej było w przypadku emigracji zdemobilizowanych żołnierzy polskich do Kanady, gdzie zwykle byli kierowani do obowiązkowej pracy fizycznej na farmach, niezależnie od posiadanego wykształcenia i zawodu wykonywanego przed wojną. To była pomoc oferowana osobom biorącym czynny udział w walkach o wyzwolenie, jak się okazało, tylko zachodniej Europy. W toku debaty o solidarności z uchodźcami warto ją zestawiać z formami pomocy udzielanej obecnie imigrantom przybywającym do Europy i podającym się za uchodźców politycznych oraz z ich oczekiwaniami, a bywa, że wręcz żądaniami.

Jedną z tez, która wcielana w życie ma spowodować zmianę świata, jest teza o ociepleniu klimatycznym. Zastosowana do kwestii mobilności przestrzennej służy uzasadnieniu nieodzowności, w krótkim już czasie, masowej migracji z Afryki Subsaharyjskiej na Północ, do Europy. W związku z nią nasuwają się następujące pytania: czy, po pierwsze, ocieplenie klimatyczne utrudni obecną bezprecedensową i bezwzględną rabunkową eksploatację tej ziemi i czy eksploatacja ta nie przyspiesza owego ocieplenia? Pytanie drugie dotyczy troski o ten region świata oraz jej wymiernych rezultatów i brzmi: czy i jak są wykorzystywane zasoby finansowe i możliwości technologiczne pozostające w gestii wielkiego kapitału eksploatującego obecnie Afrykę do przeciwdziałania skutkom ocieplenia klimatycznego na tym terenie oraz jego spowalniania? ${ }^{58}$ I wreszcie: czy stwierdzane ocieplenie klimatyczne przy braku (jakichkolwiek) środków spowalniających i zapobiegawczych nie służy przede wszystkim legitymizacji unięcia ludzi z tej ziemi? Interesujące jest

\footnotetext{
56 „We wrześniu 1945 w Europie było prawie dwa miliony dipsów, z czego około połowę stanowili Polacy". Roger Harris i Jerzy Jarosław Smolicz, Australijczycy polskiego pochodzenia, eeria: Biblioteka Polonijna, t. 12 (Wrocław: Zakład Narodowy im. Ossolińskich, 1984), 49.

${ }^{57}$ Ibid., 49, 64. W podpisywanym zobowiązaniu znalazło się i takie zdanie: „Jestem także świadomy, że muszę wykonywać przeznaczoną mi pracę przez około co najmniej 2 lata i że nie uzyskam zezwolenia na zmianę zatrudnienia w czasie tego okresu bez zgody Departamentu Imigracji”. Ibid., 64, przyp. 28.

${ }^{58} \mathrm{O}$ możliwościach współczesnych technologii przekonują dokonania krajów arabskich Zatoki Perskiej, budujących życie dosłownie na wyspach z piasku.
} 
też, czy argumentacji na rzecz owego „przesunięcia” całej ludności z jednego regionu świata w inny jego region i jej naukowej legitymizacji towarzyszy namysł nad ekologicznymi skutkami masowej migracji m.in. do Europy, w tym do Polski, już obecnie zagrożonej brakiem wody. Zawarte w postawionych pytaniach kwestie dają asumpt do przypuszczenia, że omawiana teza to kolejne narzędzie przebudowy świata, jaki znamy.

\section{BIBLIOGRAFIA}

BARTH, Frederik. „Grupy i granice etniczne: społeczna organizacja różnic kulturowych”. W: $B a-$ danie kultury. Elementy teorii antropologicznej. Kontynuacje, red. Marian Kempny i Ewa Nowicka, 348-377. Warszawa: Wydawnictwo Naukowe PWN, 2004.

DACYL, Janina W. An emerging international temporary protection regime. W: Likeverdighet og utestengning - forskningsmessige utfordringer, red. John Ch. Knudsen. Sztokholm: Tema Nord, 1996.

DzIĘGIEL, Ewa. „Warunki funkcjonowania pracy polskojęzycznej na Ukrainie sowieckiej w latach 20. i 30. XX wieku”. W: Ewa DzięGiel, Katarzyna Czarnecka, Dorota A. Kowalska, Lyudmyla Yanushevska, Polskojęzyczna prasa na Ukrainie sowieckiej w latach 1918-1939: przegląd tytutów i treści, 52-65. Kraków: Instytut Języka Polskiego PAN, 2016.

Encyklika Sollicitudo rei socialis. W: Encykliki Ojca Świętego Jana Pawła II. Kraków: Dom Wydawniczy Rafael, 2009.

Gogacz, Mieczysław. Szkice o kulturze. Warszawa-Struga: Wydawnictwo Michalineum, 1985.

HANSEN, Miriam Bratu. „Masowe wytwarzanie doświadczenia zmysłowego. Klasyczne kino hollywoodzkie jako modernizm wernakularny". Przeł. Łukasz Biskupski, Monika Murawska, Michał Pabiś, Justyna Stępień, Tomasz Sukiennik, Monika Żurawska. W: Rekonfiguracje modernizmu, red. Tomasz Majewski, 235-266. Warszawa: Wydawnictwa Akademickie i Profesjonalne, 2009.

Harris, Roger, i Jerzy Jarosław Smolicz. Australijczycy polskiego pochodzenia. Seria: Biblioteka Polonijna, t. 12. Wrocław: Zakład Narodowy im. Ossolińskich, 1984.

KIEżun, Witold. Patologia transformacji. Warszawa: Wydawnictwo Poltext, 2012.

Око́Lski, Marek, i Agnieszka Fihel. Demografia. Wspótczesne zjawiska i teorie. Warszawa: Wydawnictwo Naukowe Scholar, 2012.

Okólski, Marek, i Agnieszka Radziwinowiczówna. „Współczesne migracje na świecie”. W: 25 wykładów o migracjach, red. Magdalena Lesińska i Marek Okólski, 101-127. Warszawa: Wydawnictwo Naukowe Scholar, 2018.

ОкóLSKI, Marek. „Illegality of International Population Movements in Poland”. International Migration" 38 (2000), issue 3: 57-89.

Oко́LSKI, Marek. „Migration Pressures on Europe”. W: European Populations: Unity in Diversity, red. Dirk van de Kaa, Henri Leridon, Giuseppe Gesano i Marek Okólski. Dordrecht: Kluwer Academic Press, 1999.

Romaniszyn, Krystyna. „Migracje a zmiana celowa”. Studia Polonijne 40 (2019): 5-32.

Romaniszyn, Krystyna. „Migracje polityczno-ekonomiczne jako fenomen współczesności”. W: Mi- 
gracje polityczne XX wieku, red. Jan E. Zamojski, 86-100. Seria: Migracje i społeczeństwo, t. 4, Warszawa: Wydawnictwo Neriton, 2000.

RomANISZYN, Krystyna, „Odrodzenie rasizmu jako element przemian kulturowych implikowanych przez międzynarodowe migracje”, Studia Polonijne 23 (2002): 7-31.

Romaniszyn, Krystyna. „Polacy w Grecji. Cz. I: Współczesna masowa migracja zarobkowa z Polski do Grecji”. Studia Polonijne 16 (1994): 7-42.

RomanisZyn, Krystyna. „Światowe szlaki migracyjne: przemiany i kontynuacje”, w: Migracje 1945-1995, red. Jan E. Zamojski, 55-68. Seria: Migracje i społeczeństwo, t. 3. Warszawa: Wydawnictwo Neriton, 1999.

RomaniszYn, Krystyna. „The immigrant as a non-invented other”. Studia Polonijne 39 (2018): 5-26.

SARAH, Robert., i Nicolas Diat. Wieczór się zbliża i dzień już się chyli. Warszawa: Wydawnictwo SS. Loretanek, 2019.

\section{MATERIALY PRASOWE I INTERNETOWE}

Doleśniak-HarczuK, Olga. „Niechciane dziecko Willkommenskultur”. Nowe Państwo 2019, nr 2. Dostęp: 31.07.2020. https://www.panstwo.net/4785-niechciane-dziecko-willkommenskultur.

Frum, David. „How much immigration is too much?” The Altantic 2019, April issue. Dostęp: 31.07.2020. https://www.theatlantic.com/magazine/archive/2019/04/david-frum-how-much-immi gration-is-too-much/583252/.

Kurier Wnet, nr 63, wrzesień 2019, rubryka Telegraf. Dostęp: 31.07.2020. https://wnet.fm/ issues/nr-63-wrzesien-2019/.

Pew Research Center. Dostęp: 04.11.2018. http//www.pewglobal.org/2018/03/22.

PP. „Migracyjny strach spadł na Lizbonę”. Gazeta Polska Codziennie z 14.12.2019. Dostęp: 31.07.2020. https:// gpcodziennie.p1/124020-migracyjnystrachspadlnalizbone.html.

„Słabnie fala nielegalnej imigracji”. Gazeta Polska Codziennie z 17.12.2019.

Wysocki, Konrad. „Europa u progu kolejnego kryzysu”. Gazeta Polska Codziennie z 9.10.2019. Dostęp: 31.07.2020. https://gpcodziennie.pl/121128-europa-uprogu-kolejnego-kryzysu.html.

\section{W OBLICZU KOŃCA EUROPY, JAKĄ ZNAMY}

\section{Streszczenie}

Przedmiotem artykułu jest namysł nad masową migracją jako współczynnikiem zmiany społeczeństw europejskich i ogólnie europejskiej cywilizacji. Zostały w nim wykorzystane dane statystyczne dotyczące globalnej mobilności ze szczególnym uwzględnieniem napływów z Południa do Europy. W centrum uwagi znalazły się następujące wątki: rozmiary imigracji do Europy; czynniki wypychające z krajów pochodzenia imigrantów i czynniki przyciągające ich do krajów europejskich; społeczne mechanizmy i kulturowe determinanty mobilności, prawdopodobne społeczne i kulturowe konsekwencje masowej imigracji do Europy oraz jej polityczny kontekst.

Słowa kluczowe: masowe migracje; uchodźcy; globalna mobilność; czynniki wypychające i przyciągające; społeczno-kulturowe determinanty mobilności. 


\section{IN THE FACE OF THE END OF EUROPE WE KNOW}

\section{S u m m a r y}

The paper aims at discussing the issue of mass migrations as the coefficient of European societies and civilization change. The papers draws upon the statistical data regarding global migration, in particular the inflows into Europe from the South. It focuses on the following issues: the volume of inflows into Europe; the push-pull agents; the socio-cultural determinants of migration; possible socio-cultural consequences of the mass immigration to Europe and its political context.

Key words: mass migrations; refuges; global mobility; push-pull agents; socio-cultural determinants of migration. 